\title{
In Vitro Culture of Freshwater Pearl Mussel from Glochidia to Adult
}

\author{
Satit Kovitvadhi ${ }^{1}$ and Uthaiwan Kovitvadhi2,* \\ ${ }^{1}$ Department of Agriculture, Faculty of Science \\ and Technology, Bansomdejchaopraya \\ Rajabhat University, Bangkok \\ ${ }^{2}$ Department of Zoology, Faculty of Science, \\ Kasetsart University, Bangkok \\ Thailand
}

\section{Introduction}

The culture of freshwater pearl mussel is divided into three steps, i.e. glochidia, juveniles and adults. Juvenile has been successfully cultured in the laboratory by attaching glochidia to fish until they could transform into the early juvenile stage (Fukuhara et al., 1990; Panha, 1992; Buddensiek, 1995; Uthaiwan et al., 2003; Hanlon \& Neves, 2006). Furthermore, sterilized artificial media could be utilized for the culture of glochidia (to bypass the parasitic stage); the progress of this technique can be followed in a succession of reports by Isom \& Hudson (1982, 1984a,b), Keller \& Zam (1990), Uthaiwan et al. (2001, 2002), Kovitvadhi et al. (2006, 2007, 2008, 2009), Areekijeree et al. (2006), Lima et al. (2006), Supannapong et al. (2008), Srakaew et al. (2010) and Chumnanpuen et al. (2011). Moreover, some species of freshwater mussel glochidia cultured in artificial media could develop to adulthood as well as inducing gonadal development to sexual maturity and the marsupia could develop, namely Hyriopsis (Limnoscapha) myersiana (Kovitvadhi et al., 2006, 2008), Chamberlainia hainesiana (Kovitvadhi et al., submitted) and Hyriopsis (Hyriopsis) bialatus (Kovitvadhi \& Kovitvadhi., in preparation).

Therefore, in this chapter author will explain each step from preparation and culture of glochidia in artificial media as well as all techniques of rearing early juvenile through the adult. In addition, water qualities and food suitable for rearing from early juvenile until adult will be described including morphological development under light microscope and scanning electron microscope.

\section{Culture of glochidia in artificial media}

Glochidia were cultured in artificial media according to Kovitvadhi, (2000); Uthaiwan et al., (2002) and Kovitvadhi et al., (2006) until they transformed to 0-day-old juveniles. The details in each step of glochidia culture in artificial media were as follows:

${ }^{*}$ Corresponding Author 


\subsection{Composition of artificial media}

The composition of artificial media for culture of glochidia is shown in Table 1. Artificial media were based on those improved by Keller \& Zam (1990), which consisted of a modification from the formulae of Isom \& Hudson (1982). The main differences concerned the composition of the commercial media M199. While the protein source was exclusively horse serum in Keller \& Zam (1990) and common carp, Cyprinus carprio fish plasma was used as an alternative support to the medium for cultured glochidia of $H$. (L.) myersiana (Uthaiwan et al., 2002; Kovitvadhi et al., 2006, 2007, 2008, 2009), Hyriopsis (Hyriopsis) bialatus (Areekijeree et al., 2006; Supannapong et al., 2008; Srakaew et al., 2010; Chumnanpuen et al., 2011; Kovitvadhi \& Kovitvadhi., preparation), Chamberlainia hainesiana (Kovitvadhi et al., submitted) and Anodonta cygnea (Lima et al., 2006). Glochidia could transform into juvenile in the media containing common carp fish plasma as protein source. These glochidia were completely transformed within 8-11 days with a survival rate up to $93 \%$ except $34 \%$ of A. cygnea. All surviving larvae transformed into the juvenile stage except A. cygnea $<34 \%$. For these reasons, composition of artificial medium (Table 1) was according to Uthaiwan et al. (2002), based on Isom \& Hudson (1982) and Keller \& Zam (1990), was proposed for culture of glochidia.

\begin{tabular}{lll}
\hline \multicolumn{1}{c}{ Composition of media } & The ratio of artificial medium \\
\hline M199 & 2 \\
Common carp fish plasma & 1 \\
Antibiotics and antimycotic & 0.5 \\
\hline
\end{tabular}

Table 1. Composition of artificial medium for culture of glochidia

\subsection{Preparation of glochidia media}

\subsubsection{M199 preparation}

Dissolved one packet of M199 powder (Gibco, No. 6231100-035) in 1 liter volume of sterile distilled water and added $2 \mathrm{~g}$ of $\mathrm{NaHCO}_{3}$. Thereafter, M199 was filtered through 0.45 and $0.20 \mu \mathrm{m}$ filter paper, respectively and kept at $4{ }^{\circ} \mathrm{C}$.

\subsubsection{Fish plasma preparation}

Common carp was anesthetized with $50 \mathrm{mg} / 1$ of quinaldine. Fish blood was collected from the caudal vein, in the tail area, using a syringe needle no. 18 which was coated with sodium heparin at $1000 \mathrm{unit} / \mathrm{ml}$. The blood sample was placed into sterile plastic test tube and centrifuged at 1000 and $3000 \mathrm{rpm}$ for $10 \mathrm{~min}$ each. Plasma portion (clear yellow in colour) was separated and placed into the new test tube and centrifuged at $3000 \mathrm{rpm}$ for $10 \mathrm{~min}$. Then, plasma was separated and filtered through 0.45 and $0.20 \mu \mathrm{m}$ filter paper, respectively and kept at -10 to $-20^{\circ} \mathrm{C}$. 


\subsubsection{Antibiotics and antimycotic preparation}

The composition of antibiotics and antimycotic chemicals (Isom \& Hudson, 1982) is shown in Table 2.

\begin{tabular}{ll}
\hline Compound & Concentration $(\mu \mathrm{g} / \mathrm{ml})$ \\
\hline Antibiotics & 100 \\
Carbenicillin & 100 \\
Gentamicin sulfate & 100 \\
Rifampin & \\
Antimycotic & 5 \\
Amphotericin B & \\
\hline
\end{tabular}

Table 2. Combination of antibiotics and antimycotic for culture of glochidia.

\subsection{Glochidia media preparation}

Medium199 (see Section 2.2.1), fish plasma (see Section 2.2.2) and antibiotics/antimycotic (see Section 2.2.3) were mixed in the ratio 2:1:0.5, respectively (Table 1). The artificial media were divided into sterile plastic test tubes and kept at -10 to $-20{ }^{\circ} \mathrm{C}$ for stocking culture media.

\subsection{Glochidia preparation}

Adult freshwater mussel were collected from the natural habitat. They were sexually identified by microscopic observation of sperms and eggs in fluid sucked from the gonads by use of a sterile syringe. Fifteen female and fifteen male adult mussels were cultured together in a cylinder net cage (diameter $50 \mathrm{~cm} \times$ height $50 \mathrm{~cm}$ ) in an earthen pond for the production of mature glochidia. They were allowed to feed freely on natural food. After 1-2 weeks, all females were observed marsupial colour by tongs to open the shell slightly, which marsupial colour indicates the development of larval stage. In the immature stage, glochidia was yellow in colour, while partially brown colour was at the beginning of maturity. Only completely brown marsupia of gravid mussel was selected in order to examine the strong and suitable glochidia for culturing in artificial media. Thereafter, the outer shell of gravid mussel with completely brown marsupia was washed with tap water and then sterile tap water. The glochidia were sucked by using a sterilized $1 \mathrm{ml}$ syringe and discharged into depression or well slide with sterilized distilled water. Then, the glochidia were observed under a light microscope $(\times 400)$. If their shells periodically closed, they were sucked according to abovementioned. Later, they were cleaned to eradicate tissue residues, mucus and glochidia shell fragments by spraying sterilized distilled water onto them. Complete cleaning and stronger glochidia were used for culture. Glochidia from gravid mussels should be cultured in artificial media within $5 \mathrm{~h}$ after harvesting.

\subsection{Glochidia culture}

Approximately 5000-6000 glochidia were transferred into a culture dish (90×15 mm) containing $10 \mathrm{ml}$ of artificial medium (Table 1). The culture dishes were placed in a lowtemperature incubator at $25{ }^{\circ} \mathrm{C}$ with $5 \% \mathrm{CO}_{2}$. The culture medium was removed and replaced with fresh medium in the middle of cultured period. Finally, $4 \mathrm{ml}$ of sterilized 
distilled water was added to the culture dish to stimulate the transformation when the mantle (Fig. 1A) was observed before 1 day of transformation from glochidia into juveniles. Juvenile transformation was observed under a light microscope $(\times 400)$ for the movement of juvenile foot (Fig. 1B) and also juvenile movement as an indicator of the glochidia transformation success into juvenile stage.
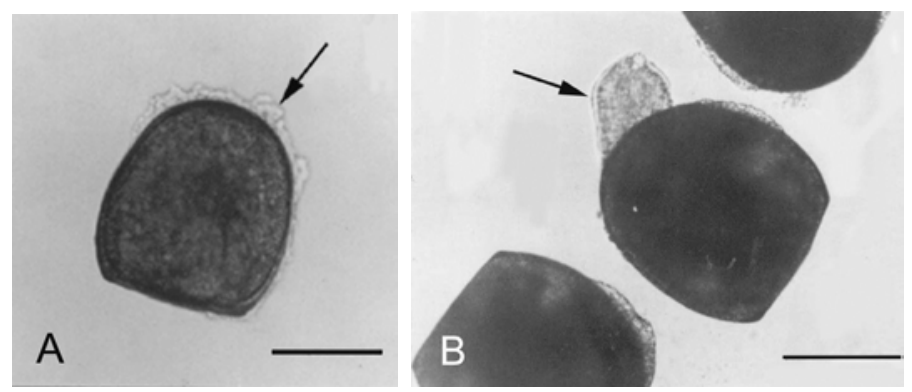

Fig. 1. Light microscope of glochidial development to early juvenile. A; Glochidial development with the mantle edge bordering shell outside (arrow). B; Early juvenile with a foot (arrow). Bar $=100 \mu \mathrm{m}$ (Uthaiwan et.al., 2001).

\section{Selection of phytoplankton food species for juveniles}

Phytoplankton has proven to be a vital source of nutrient for several species of freshwater mussel juveniles (Hudson \& Isom, 1984; Gatenby et al., 1996; Gatenby et al., 1997; ÓBeirn et al., 1998; Uthaiwan et al., 2001). Moreover, Kovitvadhi et al. (2000) reported that phytoplankton contributed to $99 \%$ of the gastrointestinal tract content of the adult freshwater pearl mussel, $H$. (L.) myersiana in natural habitat. Consequently, phytoplankton from the gastrointestinal tract of adult were cultured and selected for juvenile feeding. Collecting mussels of different sizes from natural habitat, which phytoplankton existed in the gastrointestinal tract then it was cutting and sucking to culture in sterilized water with f/2 media (Guillard \& Ryther, 1962). Then, they were cultured under light not less than 10,000 Lux for $12 \mathrm{~h}$ as well as in mixed about 3\% carbon dioxide. From there, phytoplankton to be cultured were in the process of sub-culture and purified every 2-10 days by streak plating technique (Hoshaw \& Rosowski, 1973). Streak plates were placed under light until the single colonies of phytoplankton appeared which might last for 10-30 days. Thereafter, those phytoplankton were kept in slant tube. Whenever phytoplankton were required for feeding juveniles, those phytoplankton were multiplied in 1 liter bottle by using the same separated formulae. Kovitvadhi et al. (2006) as abovementioned found ten species of phytoplankton; Ankistrodesmus gracilis, Chlamydomonas sp., Chlorella sp.1, Chlorella sp.2, Kirchneriella incurvata, Monoraphidium sp., Navicula sp., Scenedesmus sp., Stichococcus sp. and Coccomyxa sp. Thereafter, all phytoplankton were selected for suitable cultured juvenile which should be considered based on 6 criteria according to Areekijseree et al. (2006); Kovitvadhi et al. (2006); Supannapong et al., (2008): (1) size (2) capability of filter into gastrointestinal tract by observing under microscope within $30 \mathrm{~min}$ and $1.30 \mathrm{~h}$ after giving phytoplankton (3) the movement of cilia at gill, mantle and foot by observing under microscope (4) color changes in gastrointestinal tract which should be from green to yellow or brown and shape from normal to debris (5) carbohydrate and protein contents of 
phytoplankton (6) efficiency of digesting carbohydrate and protein of phytoplankton by using crude enzyme extracts from juveniles (in vitro digestibility). The major phytoplankton were suitable for culturing juvenile of freshwater mussel, namely Chlorella sp. 2 and $K$. incurvata (Table 3).

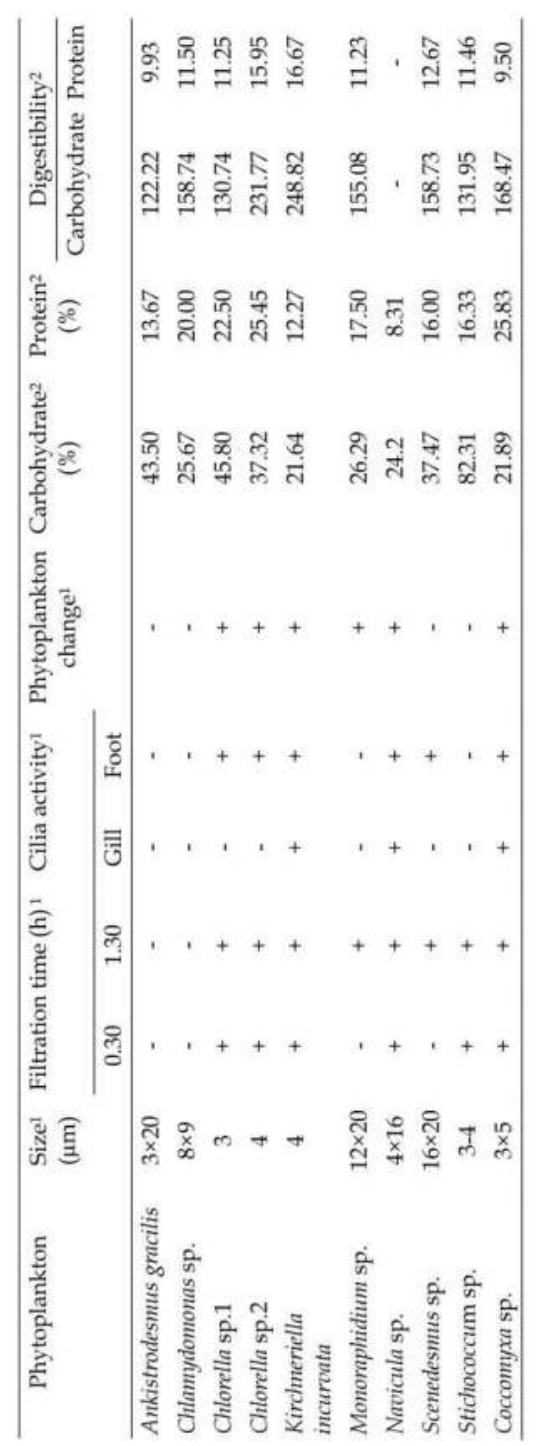

Table 3. Characteristic of phytoplankton isolation from gastrointestinal tract of adult freshwater mussel in natural habitat and in vitro digestibility for carbohydrate ( $\mu$ g maltose mg plankton ${ }^{-1}$ ) and protein ( $\mu$ g DL-alanine equivalent mg plankton ${ }^{-1}$ ) of ten algal species at seven days old, using crude enzyme extracts from 30 -day-old juveniles. ${ }^{1}$ Kovitvadhi et al. (2006), ${ }^{2}$ Supannapong et al. (2008). 


\section{Juvenile culture}

After glochidia transformed to juvenile in artificial medium, water of recirculating aquaculture system was added in the ratio of medium to water equaled 3:1, 1:1, 1:3 for 30 min, added $K$. incurvata and Chlorella sp. in ratio $1: 1$ at density of $1 \times 10^{5}$ cells per $\mathrm{ml}$ in ratio medium to water equaled 1:3. From there, cultured juvenile was transferred to culture units. Culture of juvenile stage could be divided into 3 stages, namely first stage beginning from 0 days old juvenile until two shell mussel completely closed. Kovitvadhi et al. (2008) cultured juvenile 0-120 days old of freshwater mussel, $H$. (L.) myersiana by recirculating aquaculture system (Fig. 2). This system comprised of three filter cabinets made of $6 \mathrm{~mm}$ thick acrylic (particulate filter cabinet, macrophytes filter cabinet and biological filter cabinet), one water resting cabinet (Fig. 2E) and nine plastic culture units (Fig. 2F). The size of particulate filter cabinet (Length $\times$ Width $\times$ Height $\times$ Water level $=46 \times 35 \times 51 \times 42 \mathrm{~cm}$ ) was divided into two equal parts, of which the first part was filled with a $30 \mathrm{~cm}$ thick nylon filter (Fig. 2B). Water flowed through this filter and via the second to the macrophytes filter cabinet. The size of macrophytes filter cabinet (Length $\times$ Width $\times$ Height $\times$ Water level $=80 \times 40 \times 51 \times 42 \mathrm{~cm}$ ) was divided into four equal units. Each unit contained 57 ambulia plants, Limnophila heterophylla (Raxb.) Bentham; these, 228 plants in total, were introduced when they were $6 \mathrm{~cm}$ in height and had an average weight of $2.69 \pm 0.13 \mathrm{~g}$ (Fig. 2C). The plants were removed and replaced when their tips reached the water surface. The upper parts of the cabinets were equipped with three fluorescent lamps (each $20 \mathrm{~W}$ ) $25 \mathrm{~cm}$ above the water surface (light intensity at water surface equal to 5320 lux; $24 \mathrm{~h}$ ) (Fig. 2G). The water then flowed into the biological filter cabinet $(60 \times 34 \times 51 \times 42 \mathrm{~cm})$ filled with bioball to full capacity (Fig. $2 \mathrm{D})$ and then to the resting cabinet $(46 \times 41 \times 51 \times 42 \mathrm{~cm})$. In the resting cabinet there were two water pumps: The first returned water to the particulate filter cabinet at the rate of 11 per minute continuously and the second pumped water at $20 \mathrm{ml}$ per minute to nine plastic culture units (each $84 \times 14 \times 15 \times 7 \mathrm{~cm}$ ). This pump was stopped for $1 \mathrm{~h}$ after phytoplankton was introduced into the culture unit. The bottom of the culture unit was filled with sand $(<120 \mu \mathrm{m})$ at 0.27 $\mathrm{g} / \mathrm{cm}^{2}$. The inside of the culture unit was divided into two section, as described previously, but of different sized (section $1-66.1 \times 14 \times 15 \times 7 \mathrm{~cm}$; section $2-17.9 \times 14 \times 15 \times 7 \mathrm{~cm}$ ). The first section also consisted of five acrylic sheets jutting from the walls on alternate sides. Juveniles were fed Chlorella sp. and K. incurvata. Each species of algae was collected from the 1001 by being pumped through $0.3 \mu \mathrm{m}$ ceramic filters and then separated from the water by centrifuging at $8000 \times \mathrm{g}$. The sediments of the two algal species were mixed at a ratio of 1:1 wet weight and kept in a freezer. When required, the mixture was brought to room temperature then sucked by Pasteur pipette into the all plastic culture unit to an algae density of $1 \times 10^{5}$ cells per ml. Algae were supplied twice a day $(06.00 \mathrm{~h}$ and $18.00 \mathrm{~h})$, and the frozen stock was usually used within 7 days of collection.

Second stage, thirty-five juveniles (120 days old) were transferred to culture units $(20 \times 12 \times 72$ $\mathrm{cm})$. The culture units had all four vertical sides lined with nylon net $(0.42 \mathrm{~mm}$ mesh size) and each had a plastic lid with holes to cover the top. The lower part of the culture unit consisted of a section $2 \mathrm{~cm}$ in height, which fitted snugly into the culture unit, from which it could be removed (Fig. 3). This lower part contained $400 \mathrm{~g}$ of sand ( $<425 \mu \mathrm{m}$ in size). The juveniles were placed directly on the sand. The culture unit was then hung in the earthen pond; the base of the culture unit was adjusted to a position approximately $50 \mathrm{~cm}$ below the water surface. The juveniles fed by filtering phytoplankton from the water in the earthen pond. All mussels from the culture unit were rinsed every 10 days. 

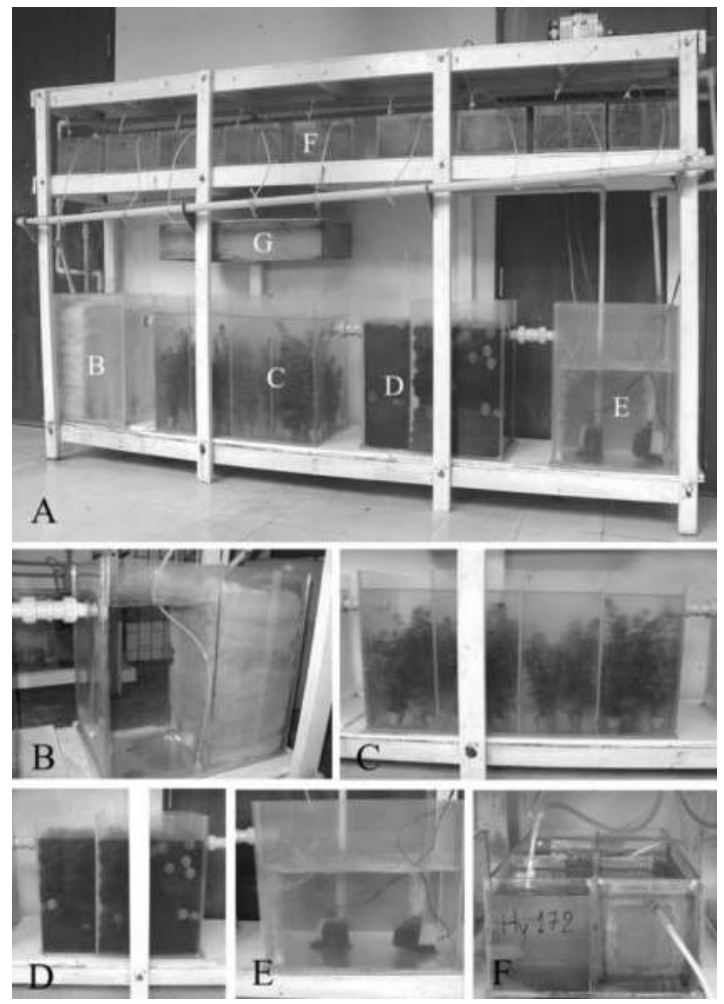

Fig. 2. Photographs of the recirculating used to rear freshwater pearl mussel juveniles. A; Recirculating aquaculture system, B; Particulate filter cabinet, C; Macroplants filter cabinet, D; Biological filter cabinet, E; Water resting cabinet, F; Plastic culture unit, G; Fluorescent box.

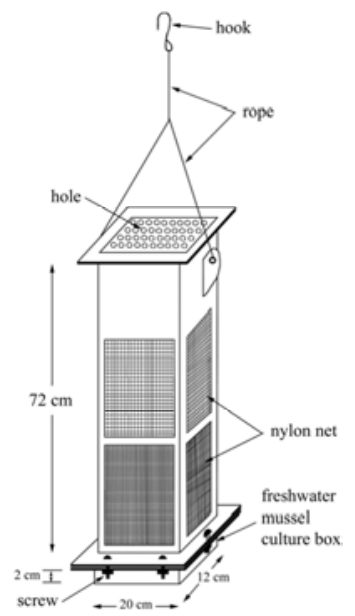

Fig. 3. Rearing container of juveniles (Kovitvadhi et al., 2006). 
Third stage, juveniles (180 days old) were transferred to culture into natural habitat or the earthen pond by a cylinder net cage until adult.

\section{Adult culture}

At present, adult of some species freshwater pearl mussels had been successfully cultured in an earthen pond and natural habitat. They had high survival and could produce glochidia stage such as $H$. (L.) myersiana (Uthaiwan et al., 2002; Kovitvadhi et al., 2006, 2007, 2008, 2009), H. (H.) bialatus (Areekijeree et al., 2006; Supannapong et al., 2008; Srakaew et al., 2010; Chumnanpuen et al., 2011; Kovitvadhi \& Kovitvadhi., preparation), C. hainesiana (Kovitvadhi et al., submitted). Fifteen female and fifteen male adult mussels, were cultured together in a cylinder net cage (diameter $50 \mathrm{~cm} \times$ height $50 \mathrm{~cm}$ ). Then, it was hung under the raft (Fig. 4) at 1.5-2 $\mathrm{m}$ deep from water surface which phytoplankton were plenty at this level. The cage was shaken every week for protecting biofouling attachment which could mass mortality.

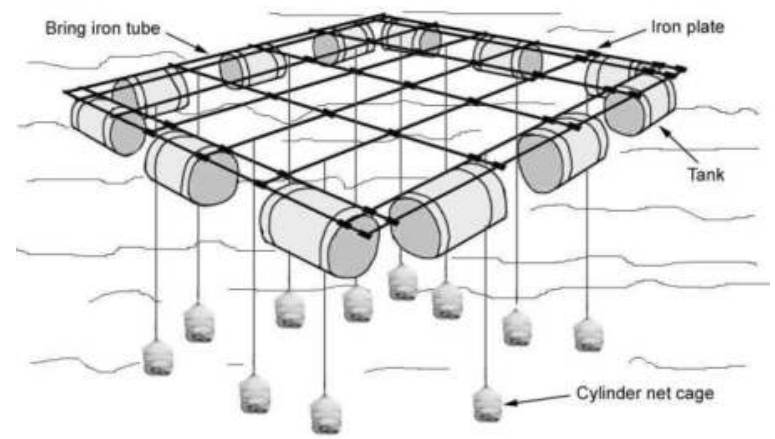

Fig. 4. Raft for adult freshwater pearl mussel culture. (Kovitvadhi, 2008).

\section{Water analysis}

Prior to culturing mussel, water quality in habitat, was studied in water improvement suitable to growth and survival which conformed to Kovitvadhi et al. $(2006,2008)$ that juvenile cultured in the laboratory and the earthen pond nearby natural habitat (Kovitvadhi et al., 1998) (Table 4). Water quality parameters should be analyzed for freshwater pearl mussel culture: water temperature, $\mathrm{pH}$, tubidity, conductivity, dissolved oxygen, total alkalinity, free carbon dioxide, total hardness, total ammonia nitrogen, nitrite, nitrate, phosphorus, silica and calcium. In this connection, juvenile stage had been more sensitive to environmental changes than another stages, particularly water qualities suitable and rather stable; water temperature, $\mathrm{pH}$, free carbon dioxide, dissolved oxygen, nitrate and phosphorus and decreasing values; total alkalinity, total hardness, total ammonia nitrogen, silica, and calcium except nitrite that had increasing value (Fig. 5). When averaged water quality value was calculated to relationship with averaged survival value and shell length with equation: $Y=b_{0}+b_{1} X+b_{2} X^{2}+b_{3} X^{3}$ where $Y$ is the survival or shell length, $X$ is age (days), and $b_{0}, b_{1}, b_{2}$ and $b_{3}$ are parameters. It was found that survival of 0 -120-day-old juveniles would have direct relationship with $\mathrm{pH}$, total alkalinity, total hardness, silica and calcium with highly significant difference $(\mathrm{P}<0.01)$ and with reverse relationship to free carbon dioxide and nitrite (Table 5) (Kovitvadhi et al., 2008). 


\begin{tabular}{|c|c|c|c|c|c|}
\hline \multirow[b]{2}{*}{ Water quality } & \multicolumn{2}{|c|}{$\begin{array}{c}\text { Culturing of juvenile } \\
\text { in laboratory }{ }^{1}\end{array}$} & \multirow{2}{*}{$\begin{array}{l}\text { Culture of mussel } \\
\text { in the earthen } \\
\text { pond }{ }^{1} \\
120-360 \text { days old } \\
\text { (mean } \pm \text { SD) }\end{array}$} & \multirow{2}{*}{$\begin{array}{c}\text { Culture of } \\
\text { mussel }^{1} \\
0-360 \text { days } \\
\text { old } \\
(\text { mean } \pm S D)\end{array}$} & \multirow{2}{*}{$\begin{array}{l}\text { Mussel } \\
\text { Habitat }{ }^{2} \\
\text { (min. - } \\
\text { max.) }\end{array}$} \\
\hline & $\begin{array}{c}0-60 \\
\text { day old } \\
(\text { mean } \pm S D)\end{array}$ & $\begin{array}{c}60-120 \\
\text { day old } \\
(\text { mean } \pm S D)\end{array}$ & & & \\
\hline Water temp. $\left({ }^{\circ} \mathrm{C}\right)$ & $25 \pm 0.74$ & $28 \pm 0.54$ & $26.5 \pm 1.1$ & $24.5-28.5$ & $23.8-31.6$ \\
\hline $\mathrm{pH}$ & $7.03 \pm 0.02$ & $7.51 \pm 0.04$ & $7.65 \pm 0.46$ & $6.85-8.08$ & $6.92-8.14$ \\
\hline $\begin{array}{l}\text { Dissolved oxygen } \\
\left(\mathrm{ppmO}_{2}\right)\end{array}$ & $8.1 \pm 0.07$ & $7.5 \pm 0.04$ & $5.0 \pm 0.6$ & $4.2-8.2$ & $2.5-9.0$ \\
\hline $\begin{array}{l}\text { Total alkalinity } \\
\left(\mathrm{ppmCaCO}_{3}\right)\end{array}$ & $52 \pm 1.41$ & $52.75 \pm 0.35$ & $83.7 \pm 20.3$ & $50-114$ & $62.5-115.0$ \\
\hline $\begin{array}{l}\text { Free } \\
\text { carbondioxide } \\
\left(\mathrm{ppmCO}_{2}\right)\end{array}$ & $10 \pm 0.04$ & $4.25 \pm 0.35$ & $3.95 \pm 2.7$ & $0-10.2$ & $0-6.0$ \\
\hline $\begin{array}{l}\text { Total hardness } \\
\left(\mathrm{ppmCaCO}_{3}\right)\end{array}$ & $154 \pm 2.83$ & $123 \pm 9.90$ & $196.8 \pm 12.6$ & $121-222$ & $90-133$ \\
\hline $\begin{array}{l}\text { Ammonia } \\
\text { nitrogen } \\
\left(\mathrm{ppmNH}_{3}-\mathrm{N}\right)\end{array}$ & $0.42 \pm 0.02$ & $0.28 \pm 0.01$ & $0.44 \pm 0.19$ & $0.20-0.82$ & $0.22-0.88$ \\
\hline $\begin{array}{l}\text { Calcium } \\
\left(\mathrm{ppmCaCO}_{3}\right)\end{array}$ & $139 \pm 9.9$ & $89 \pm 4.24$ & $101.1 \pm 5.1$ & $86-142$ & $65-105$ \\
\hline $\begin{array}{l}\text { Phosphorus } \\
\text { (ppmP) }\end{array}$ & $0.12 \pm 0.06$ & $0.19 \pm 0.07$ & $0.17 \pm 0.1$ & $0.01-0.45$ & $0.08-0.88$ \\
\hline Silica $($ ppmSiO 2$)$ & $4.85 \pm 0.6$ & $4.05 \pm 0.5$ & $5.75 \pm 1.6$ & $3-8$ & $0.2-5.5$ \\
\hline
\end{tabular}

${ }^{1}$ Kovitvadhi et al. (2006), ${ }^{2}$ Kovitvadhi et al. (1998).

Table 4. Water quality during culturing of 0-360 day-old juveniles and the adult mussel habitat of $H$. (L.) myersiana in the Mae Klong River, Kanchanaburi Province.

\begin{tabular}{lccc}
\hline \multicolumn{1}{c}{ Parameter } & Survival & Shell length & Shell height \\
\hline Water temperature & $-0.093^{n s}$ & $0.075^{n s}$ & $0.107^{n s}$ \\
pH & $0.716^{* *}$ & $-0.597^{*}$ & $-0.590^{*}$ \\
Dissolved oxygen & $-0.118^{n s}$ & $-0.055^{n s}$ & $-0.035^{n s}$ \\
Total alkalinity & $0.841^{* *}$ & $-0.849^{* *}$ & $-0.827^{* *}$ \\
Free carbon dioxide & $-0.634^{*}$ & $0.481^{n s}$ & $0.476^{n s}$ \\
Total hardness & $0.769^{* *}$ & $-0.764^{* *}$ & $-0.751^{* *}$ \\
Total ammonia nitrogen & $-0.152^{n s}$ & $-0.051^{n s}$ & $-0.061^{n s}$ \\
Nitrite & $-0.716^{* *}$ & $0.709^{* *}$ & $0.688^{* *}$ \\
Nitrate & $0.203^{n s}$ & $-0.200^{n s}$ & $-0.218^{n s}$ \\
Phosphorus & $0.003^{n s}$ & $-0.085^{n s}$ & $-0.091^{n s}$ \\
Silica & $0.914^{* *}$ & $-0.913^{* *}$ & $-0.091^{* *}$ \\
Calcium & $0.817^{* *}$ & $-0.751^{* *}$ & $-0.761^{* *}$ \\
\hline
\end{tabular}

Table 5. Coefficient of correlation between average survival rate and water quality; average growth rate and water quality of juvenile $H$. (L.) myersiana cultured in recirculating aquaculture system every 10 days. (Kovitvadhi et al., 2008) $\left({ }^{*}=P<0.05,{ }^{* *}=P<0.01, n s=\right.$ not significant difference, $P>0.05$ ). 

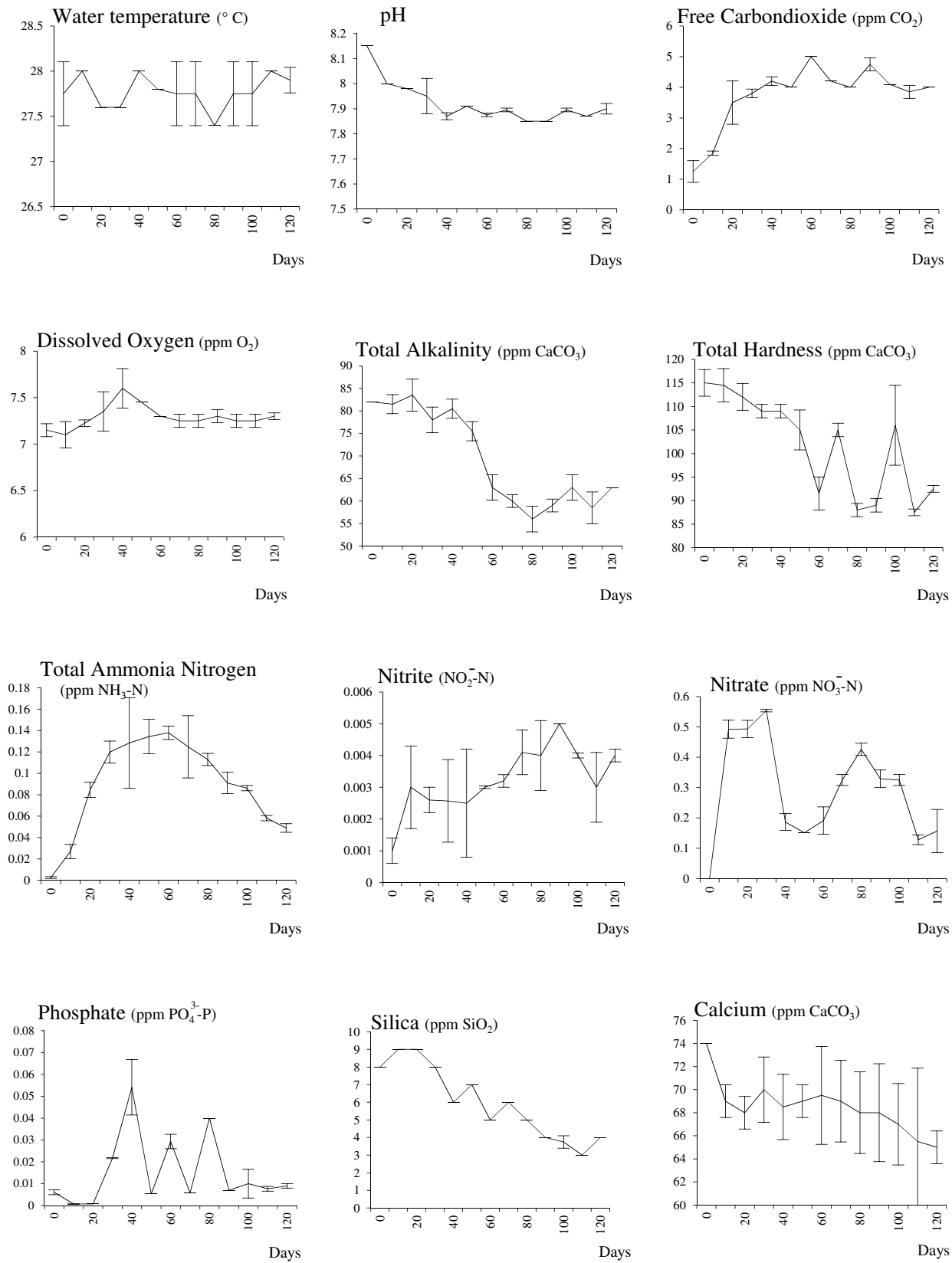

Fig. 5. Water quality during culture for 0-120 days of Hyriopsis (Limnoscapha) myersiana juveniles in recirculating aquaculture system (Kovitvadhi et al., 2008). 


\section{Phytoplankton communities}

Phytoplankton was found in the gastrointestinal tract, which it was a source of nutrient for several species of freshwater mussel (Hudson and Isom, 1984; Gatenby et al., 1996; Gatenby et al., 1997; ÓBeirn et al., 1998; Kovitvadhi et al., 2000, 2001). This finding is consistent with gut content analyses from other bivalve species (Gale \& Lowe, 1971; Huca et al., 1983; Paterson, 1986; Parker et al., 1998). From abovementioned data, it is confirmed that freshwater pearl mussels will filter phytoplankton as the main food. Therefore, culture of freshwater pearl mussels from juvenile to adult, it is necessary to have available phytoplankton species used as food for juvenile and in suitable amount throughout culturing period both in the laboratory and natural resource since freshwater mussel has to filter phytoplankton all the time. Thus, density of phytoplankton used for feeding juvenile or adult is not necessary in surplus but the food must be available throughout the culturing period which will result in increasing survival and growth.

\section{Morphological development of freshwater mussel}

Since the glochidia freshwater pearl mussel of $H$. (L.) myersiana was cultured in the artificial media that could develop to the adult (Kovitvadhi et al., 2006). Therefore, Kovitvadhi et al. (2007) could study for the morphological development of the juvenile through the adult $H$. (L.) myersiana. The mussels were collected in sequential developmental stages between 0 and 360 days old. Morphological development was observed by light microscope and SEM. SEM observations were prepared in fixative solution containing $10 \%$ neutral buffered formalin for $24 \mathrm{~h}$ and stored in $5 \%$ neutral buffered formalin for further process. The samples for SEM were thoroughly washed under running water for $30 \mathrm{~min}$ and then dehydrated in a graded series of ethanol and dried to critical point. Thereafter, they were mounted on SEM specimen stubs with conductive silver paint and coated with gold and observed with a Jeol Model JSM-5410LV scanning electron microscope operated at $25 \mathrm{KV}$. All samples before fixation, they were anesthetized in $2 \%$ chloral hydrate to observe the internal regions.

The morphological development of $H$. (L.) myersiana juveniles in culture (0-360 days old) is shown in Fig. 6. The early juvenile of $H$. (L.) myersiana at 0 days old after transformation has semi-oval, equivalve shells with an equilateral valve, presenting the same size and shape as the glochidium (Fig. 6A). Anterior shell growth was clearly seen in the first day of juvenile development (Fig. 6B), while posterior shell growth followed afterwards (Fig. 6C). The shells of 0-40-day-old juveniles were thin and transparent as seen under light microscope (Fig. 6D). The inner organs (i.e., stomach, intestine, gills, heart, foot, mantle, and cilia at the gills, mantle and foot) were clearly observed through the shell in this period (Fig. 6E). The shell, however, became thicker during the developmental process and covered all the inner organs (Figs. 6EL). The first anterior and posterior wings appear in 50-day-old juveniles (Fig. 6E), with the posterior wing becoming dominant relative to the anterior from the 140-day-old stage (Fig. $6 \mathrm{H}$ ). The mantle lobes of 0-50-day-old juveniles are joined dorsally and are free ventrally (Fig. $6 \mathrm{~F}$ ). The incurrent siphon and excurrent siphon appear after 50 days (Figs. 6G-6L). The complete adult morphology is apparent from 160 days old (Fig. 6I). Males and females reproductive organs are sexually mature about 270-360 days old mussel which depend on environment (Kovitvadhi et al., 2006; Srakaew et al., 2010) (Figs. 6K-6L). 


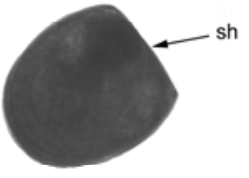

A

$\overline{50 \mu m}$
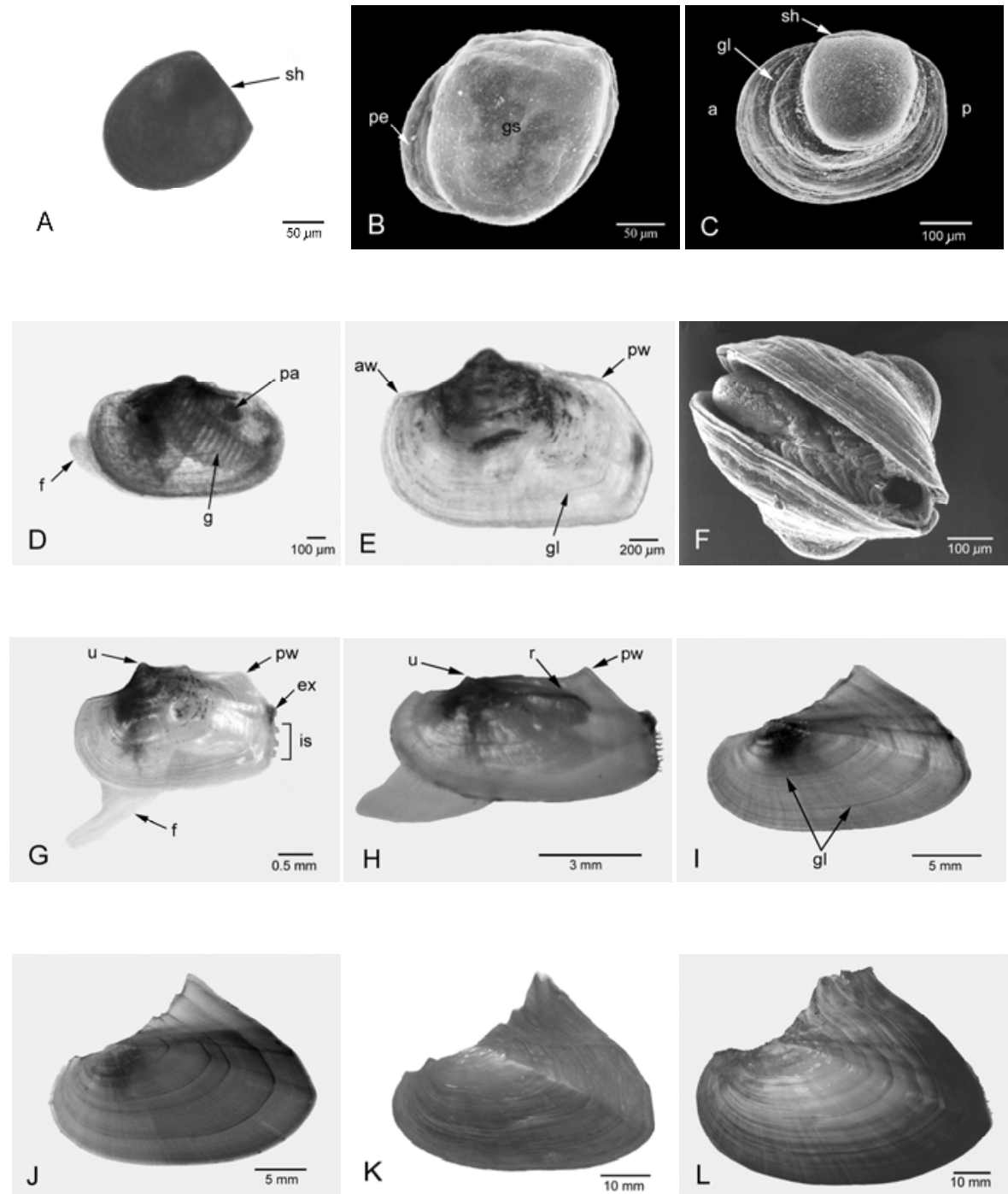

A; Light microscopy of early juvenile (after transformation, 0-day-old) shell, note shell hinge (sh). B; SEM micrograph of 1-day-old juvenile, appearance in anterior region of new soft periostracum (pe), note glochidium shell (gs). C; Juvenile 10 days old, anterior (a) region appears before and grows more than the posterior (p), note growth line (gl). D; Light microscopy of development of shell, 40-day-old juvenile, note foot (f), gill (g), posterior adductor muscle (pa). E; Light microscopy of development of shell, 50-day-old juvenile, note anterior wing (aw); posterior wing (pw). F; SEM of ventral side of 50day-old juvenile. G; Light microscopy of external morphology of 90-day-old juvenile, note excurrent siphon (es), incurrent siphon (is), umbo (u). H; Light microscopy of external morphology of 140-day-old juvenile, note rectum (r). I-L; External morphology of shell, 160, 180, 270 and 360 days old, respectively.

Fig. 6. Morphological development of 0-360-day juveniles of Hyriopsis (Limnoscapha) myersiana. (Kovitvadhi et al., 2006; 2007). 


\section{Summary}

Culture of freshwater pearl mussel is divided into the three consecutive steps: (1) culture of glochidia larvae in artificial media, (2) rearing juveniles and (3) rearing adult. The results of several studies indicate that glochidia in some species of freshwater mussel could be cultured in artificial media containing mixtures of M199, common carp plasma, antibiotics and antimycotic, and could have fully developed adult and gametogenesis was complete. The important factors in juvenile culture included culturing systems, water quality, substrate (sand) and food. The laboratory-scale recirculating aquaculture system, which water quality change was rather stable and sand could attached materials for food such as organic matter or microorganisms. Furthermore, the juveniles can burrow into the sand as they do in nature, and this helps them to prevent the attachment to the shell of feces and pseudofeces with many protozoa and later flatworms and eventual death of the juveniles. However, the size of sand should appropriate for each size of the juvenile. Phytoplankton was a vital source of nutrients, which has suitable size and shape to move into the mouth of the juveniles so that juveniles can digest them. Prior to transfer to outdoor, mussel organs have to fully developed for ingesting food, particularly gills, the incurrent and excurrent siphon, and their shells must close completely. Moreover, the water quality and food were also important factors to growth and survival.

\section{Acknowledgments}

We thank the Department of Aquaculture, Faculty of Fisheries, Kasetsart University, for providing a pond for culturing the mussels. We are very grateful to Director of the Kanchanaburi Inland Fisheries Development Center, Department of Fisheries and Mrs. Oodeum Meejui, whose supply of freshwater mussel Chamberlainia hainesiana was greatly appreciated.

\section{References}

Areekijseree, M., Engkagul, A., Kovitvadhi, S., Kovitvadhi, U., Thongpan, A. \& Rungruangsak Torrissen, K. (2006). Development of digestive enzymes and in vitro digestibility of different species of phytoplankton for culture of early juveniles of the freshwater pearl mussel, Hyriopsis (Hyriopsis) bialatus Simpson 1900. Invertebrate Reproduction and Development 49, pp. 255-262, ISSN 2157-0272

Buddensiek, V. (1995) The culture of juvenile freshwater pearl mussels Margaritifera margaritifera L. in cages: a contribution to conservation programmes and the knowledge of habitat requirements. Biological Conservation 74, pp. 33-40, ISSN 00063207

Chumnanpuen, P., Kovitvadhi, U., Chatchavalvanich, K., Thongpan, A. \& Kovitvadhi, S. (2011) Morphological development of glochidia in artificial media through early juvenile of freshwater pearl mussel, Hyriopsis (Hyriopsis) bialatus. Invertebrate Reproduction and Development 55, pp. 40-52, ISSN 2157-0272

Fukuhara, S., Nakai, I. \& Nagata, Y. (1990) Development of larvae of Anodonta woodiana (Bivalvia) parasitized on host fish. Venus 49, pp. 54-61, ISSN 0042-3580 
Gale, W.F. \& Lowe, R.L. (1971) Phytoplankton ingestion by the fingernail clam, Sphaerium transersum (Say), in pool 19, Mississippi River. Ecology 52, pp. 507-512, ISSN $0012-$ 9658

Gatenby, C.M., Neves, R.J. \& Parker, B.C. (1996) Influence of sediment and algal food on cultured juvenile freshwater mussels. Journal of the North American Benthological Society 15, pp. 597-609, ISSN 0001-4966

Gatenby, C.M., Parker, B.C. \& Neves, R.J. (1997) Growth and survival of juvenile rainbow mussels Villosa iris (Lea, 1829) (Bivalvia: Unionidae), reared on algal diets and sediment. American Malacological Society 14, pp. 57-66, ISSN 1000-3207

Guillard, R.R.L. \& Ryther, J.H. (1962) Studies of marine planktonic diatoms. I Cyclotella nana Hustedt and Detonula confervacea (Cleve). Gran. Canadian Journal of Microbiology 8, pp. 229-239, ISSN 0008-4166

Hanlon, S.D. \& Neves, R.J. (2006) Seasonal growth and mortality of juveniles of Lampsilis fasciola (Bivalvia: Unionidae) released to a fish hatchery raceway. American Malacological Bulletin 21, pp. 45-49, ISSN 0740-2783

Hoshaw, R.W. \& Rosowski, J.R. (1973) Methods for microscopic algae. In: Stein, J.R. (ed.), Handbook of Phycological Methods, Culture Methods and Growth Measurements. Cambridge University Press, USA. ISBN 0-521-20049-0

Huca, G.A., Brennerand, R.R. \& Niveiro, M.H. (1983) A study of the biology of Diplodon delodontus (Lamarck, 1819). Veliger 25, pp. 51-58, ISSN 0042-3211

Hudson, R.G. \& Isom, B.G. (1984) Rearing juveniles of the freshwater mussels (Unionidae) in a laboratory setting. Nautilus 98, pp. 129-135, ISSN 0028-1344

Isom, B.G. \& Hudson, R.G. (1982) In vitro culture of parasitic freshwater mussel glochidia. The Nautilus 96, pp. 147-151, ISSN 0028-1344

Isom, B.G. \& Hudson, R.G. (1984a) Freshwater mussels and their fish hosts; physiological aspects. Journal for Parasitology 70, pp. 318-319, ISSN 0022-3395

Isom, B.G. \& Hudson R.G. (1984b) Culture of freshwater mussel glochidia in an artificial habitat utilizing complex liquid growth media. U.S. Patent 4449480

Keller, A.E. \& Zam, S.G. (1990) Simplification of in vitro culture techniques for Freshwater mussels. Environment Toxicology and Chemistry 9, pp. 1291-1296, ISSN 0730-7268

Kovitvadhi, S. (2008) In vitro culture of freshwater mussel juvenile Hyriopsis(Limnoscapha) myersiana (Lea, 1856). Ph.D. Thesis. University of Porto, Portugal.

Kovitvadhi S., Kovitvadhi U. \& Meejui O. 2011.Growth and survival of the freshwater pearl mussel Chamberlainia hainesiana (Lea, 1856) from juvenile to adult reared in different densities and locations. Aquaculture (submitted)

Kovitvadhi, S., Kovitvadhi, U., Sawangwong, P. \& Machado, J. (2007) Morphological development of the juvenile through to the adult in the freshwater pearl mussel, Hyriopsis (Limnoscapha) myersiana, under artificial culture. Invertebrate Reproduction and Development 50, pp. 207-218. ISSN 2157-0272

Kovitvadhi, S., Kovitvadhi, U., Sawangwong, P. \& Machado, J. (2008) A laboratory-scale recirculating aquaculture system for juveniles of freshwater pearl mussel Hyriopsis (Limnoscapha) myersiana (Lea, 1856). Aquaculture 49, pp. 255-262, ISSN 0044-8486

Kovitvadhi, S., Kovitvadhi, U., Sawangwong, P., Thongpan, A. \& Machado, J. (2006) Optimization of diet and culture environment for larvae and juvenile freshwater 
pearl mussels, Hyriopsis (Limnoscapha) myersiana (Lea, 1856). Invertebrate Reproduction and Development 49, pp. 61-70, ISSN 2157-0272

Kovitvadhi, S., Kovitvadhi, U., Sawangwong, P., Trisaranuwatana, P. \& Machado, J. (2009) Morphometric relationship of weight and length of cultured freshwater pearl mussel, Hyriopsis (Limnoscapha) myersiana (Lea, 1856) under laboratory conditions and the earthen pond phases. Aquaculture International 17, pp. 57-67, ISSN 09676120

Kovitvadhi, U. (2000) Culture of glochidia of freshwater pearl mussel Hyriopsis myersiana (Lea, 1856) in artificial media. Ph.D. Thesis. University of Porto, Portugal.

Kovitvadhi, U., Chaopaknam, B., Nagachinta, A., Jongrungwit, K. \& Kulayanamit S. (1998) Ecology of freshwater pearl mussel, Hyriopsis(Limnoscapha) myersiana (Lea, 1856) in the Maeklong River, Kanchanaburi Province. Kasetsart Journal : Natural Science 32, pp. 1-12, ISSN 0075-5192

Kovitvadhi, U., Nagachinta, A. \& Aungsirirut, K. (2000) Species composition and abundance of plankton in the gut contents of freshwater pearl mussel, Hyriopsis (Limnoscapha) myersiana. Journal of Medical and Applied Malacology 10, 203-209, ISSN 1053-6388

Lima, P., Kovitvadhi, U., Kovitvadhi, S. \& Machado, J. (2006) In vitro culture of glochidia from the freshwater mussel Anodonta cygnea. Invertebrate Biolology 125, 34-44, ISSN 1077-8306

ÓBeirn, F.X., Neves, R.J. \& Steg, M.B. (1998) Survival and growth of juvenile freshwater mussels (Unionidae) in a recirculating aquaculture system. American Malacological Bulletin 14, pp. 165-171 ISSN 1000-3207

Panha, S. (1992) Infection experiment of the glochidium of a freshwater pearl mussel Hyriopsis myersiana (Lea, 1856). Venus 51, pp. 303-314, ISSN 0042-3580

Parker, B.C., Patterson, M.A. \& Neves, R.J. (1998) Feeding interactions between native freshwater mussels (Bivalvia: Unionidae) and zebra mussels (Dreissena polymorpha) in the Ohio River. American Malacological Bulletin 14, pp. 173-179, ISSN 1000-3207

Paterson, C.G. (1986) Particle-size selectivity. I The freshwater bivalve Elliptio complanata (Lightfoot). Veliger, 29, 235-237, ISSN 0042-3211

Srakaew, N., Chatchavalvanich, K., Kovitvadhi, S., Kovitvadhi, U. \& Thongpan, A. (2010) Histological structure of developing gonads in the freshwater pearl mussel, Hyriopsis (Limnoscapha) myersiana. Invertebrate Reproduction and Development 54, pp. 203-211, ISSN 2157-0272

Supannapong, P., Pimsalee, T., A-komol, T., Engkagul, A., Kovitvadhi, U., Kovitvadhi, S., \& Rungruangsak Torrissen, K. (2008) Digestive enzymes and in vitro digestibility of different species of phytoplankton for culture of the freshwater pearl mussel, Hyriopsis (Hyriopsis) bialatus. Aquaculture International 16, pp. 437-453, ISSN 09676120

Uthaiwan, K., Noparatnaraporn, N. \& Machado, J. (2001) Culture of glochidia of the freshwater pearl mussel Hyriopsis myersiana (Lea, 1856) in artificial media. Aquaculture 195, pp. 61-69, ISSN 0044-8486 
Uthaiwan, K., Pakkong, P., Noparatnaraporn, N., Vilarinho, L. \& Machado, J. (2002) Study of a suitable fish plasma for in vitro culture of glochidia Hyriopsis myersiana (Lea, 1856). Aquaculture 209, pp. 197-208, ISSN0044-8486

Uthaiwan, K., Pakkong, P., Noparatnaraporn, N., Vilarinho, L. \& Machado, J. (2003) Studies on the plasma composition of fish hosts of the freshwater mussel, Hyriopsis myersiana, with implications for improvement of the medium for culture of glochidia. Invertebrate Reproduction and Development 44, pp. 53-61, ISSN 21570272 


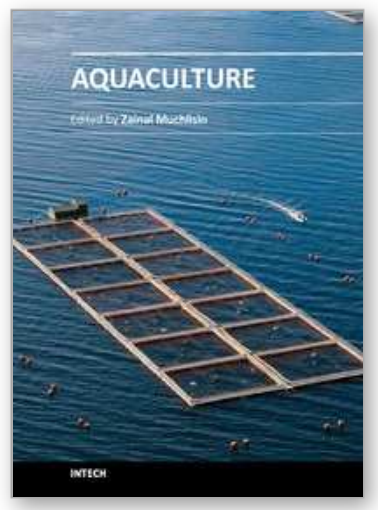

\author{
Aquaculture \\ Edited by Dr. Zainal Muchlisin
}

ISBN 978-953-307-974-5

Hard cover, 390 pages

Publisher InTech

Published online 27, January, 2012

Published in print edition January, 2012

This book provides an understanding on a large variety of aquaculture related topics. The book is organized in four sections. The first section discusses fish nutrition second section is considers the application of genetic in aquaculture; section three takes a look at current techniques for controlling lipid oxidation and melanosis in Aquaculture products. The last section is focused on culture techniques and management, , which is the larger part of the book. The book chapters are written by leading experts in their respective areas. Therefore, I am quite confident that this book will be equally useful for students and professionals in aquaculture and biotechnology.

\title{
How to reference
}

In order to correctly reference this scholarly work, feel free to copy and paste the following:

Satit Kovitvadhi and Uthaiwan Kovitvadhi (2012). In Vitro Culture of Freshwater Pearl Mussel from Glochidia to Adult, Aquaculture, Dr. Zainal Muchlisin (Ed.), ISBN: 978-953-307-974-5, InTech, Available from: http://www.intechopen.com/books/aquaculture/in-vitro-culture-of-freshwater-pearl-mussel-from-glochidia-toadult

\section{INTECH}

open science | open minds

\section{InTech Europe}

University Campus STeP Ri Slavka Krautzeka 83/A 51000 Rijeka, Croatia

Phone: +385 (51) 770447

Fax: +385 (51) 686166 www.intechopen.com

\section{InTech China}

Unit 405, Office Block, Hotel Equatorial Shanghai

No.65, Yan An Road (West), Shanghai, 200040, China 中国上海市延安西路65号上海国际贵都大饭店办公楼 405 单元 Phone: +86-21-62489820

Fax: +86-21-62489821 
(C) 2012 The Author(s). Licensee IntechOpen. This is an open access article distributed under the terms of the Creative Commons Attribution 3.0 License, which permits unrestricted use, distribution, and reproduction in any medium, provided the original work is properly cited. 